\title{
Structural setting of the Čertovka landslide (Ústí nad Labem, Czech Republic): morphostructural analysis and electrical resistivity tomography
}

\author{
Pavel RAŠKA ${ }^{1, *}$, Filip HARTVICH ${ }^{2,3}$, Vladimír $\mathrm{CAJZ}^{4,5}$ and Jiří ADAMOVIČ ${ }^{5}$ \\ 1 J. E. Purkyně University in Ústí nad Labem, Department of Geography, Faculty of Science, České mládeže 8, 40096 Ústí \\ nad Labem, Czech Republic \\ 2 Institute of Rock Structure and Mechanics, Academy of Sciences of the Czech Republic, V Holešovičkách 41, 18209 \\ Praha 8, Czech Republic \\ 3 Department of Physical Geography and Geoecology, Faculty of Science, Charles University in Prague, Albertov 6, 128 41, \\ Praha 2, Czech Republic \\ 4 Institute of Geophysics, Academy of Sciences of the Czech Republic, Boční II/1401, 14131 Praha 4, Czech Republic \\ 5 Institute of Geology, Academy of Sciences of the Czech Republic, Rozvojová 269, 16500 Praha 6 - Lysolaje, Czech Re- \\ public
}

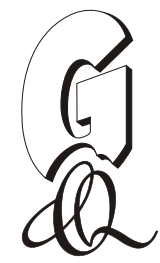

Raška P., Hartvich F., Cajz V. and Adamovie J. (2014) Structural setting of the Čertovka land slide (Ústí nad Labem, Czech Republic): morphostructural analysis and electrical resistivity tomography. Geological Quarterly, 58 (1): 85-98, doi:10.7306/gq.1134

The Čertovka landslide at Vaňov south of Ústí nad Labem, Czech Republic, is developed in a steep slope of the Labe River valley (LRV). A major episode of landsliding occurred in the first months of 1995, and the slope at Vaňov has been subjected to geological and geomorphological investigation since then. This paper presents the structural setting of the Čertovka landslide based on the latest geological survey, detailed geomorphological mapping, morphostructural analysis and results of electrical resistivity tomography. The landslide was found to be initiated at the boundary between Late Eocene to Oligocene basaltic lavas above and volcaniclastics below, with bedding dipping against the slope (anaclinal slope). The underlying volcaniclastics show tendency to argillization and have a much lower rock strength, which acts as an important factor of slope instability at the site. The Čertovka landslide is a complex slope deformation consisting of several landslides and flowslides, with boulder streams merging into a boulder accumulation further downslope. The headscarp area of the landslide developed at one of the structural levels built by basaltic lavas and forming step-like morphology of the valley slope. The headscarp coincides with the course of a regional E-W-striking Vaňov Fault that underwent multiple tectonic history and is associated with a dense fracture system including smooth slickensides on the headscarp. Structural observations combined with detailed knowledge of the anatomy of the landslide based on airborne data, surface data and geophysical data permitted to conclude on structural controls of landsliding and to predict future evolution of the slope deformation. Future landsliding will be initiated at structural levels of basaltic rocks, with the headscarps developed along fractures parallel to the Vaňov Fault. The probable gradual retreat of headscarps at the individual structural levels along the slope profile denotes a retrogressive landslide style.

Key words: landslide, structural setting, faults, volcanic complex, geophysics, Ústí nad Labem.

\section{INTRODUCTION}

The central part of the Labe/Elbe River valley (LRV) in the neovolcanic range of the České středohoři Mts. in northwestern Czech Republic is a deep erosional structure that evolved due to consequent erosion of the Labe River into the uplifting terrain of the range during the Late Cenozoic (Cajz and Valečka, 2010; Raška, 2010). Tectonically induced erosion generated steep

\footnotetext{
* Corresponding author, e-mail: pavel.raska@ujep.cz
}

Received: July 16, 2013; accepted: October 20, 2013; first published online: November 21, 2013 slopes frequently exceeding the angle of $30^{\circ}$. These slopes are formed by several superimposed volcanic bodies of different lithologies: basaltic rocks, volcanic breccias and volcaniclastic material. Underlying Cretaceous sediments of the Březno and Merboltice formations (Coniacian to Santonian) are exposed in some segments of the valley. This structural and topographic setting results in a significant mass wasting. The predisposing conditions and triggering factors of landslides have been studied from the viewpoint of landscape evolution research and landslide susceptibility mapping (Šebesta, 1997, 2000; Rybář et al., 2000a, b; Suchý, 2000; Kycl, 2003; Kycl et al., 2012).

The Čertovka landslide, located at the southern limits of Ústí nad Labem in the quarter of Vaňov (Fig. 1; $\left.50^{\circ} 37^{\prime} 17.133^{\prime \prime} \mathrm{N}, 14^{\circ} 3^{\prime} 16.057^{\prime \prime} \mathrm{E}\right)$, ranks among the largest landslides in the LRV, activated during the last two decades. The Čertovka landslide represents a complex slope deforma- 


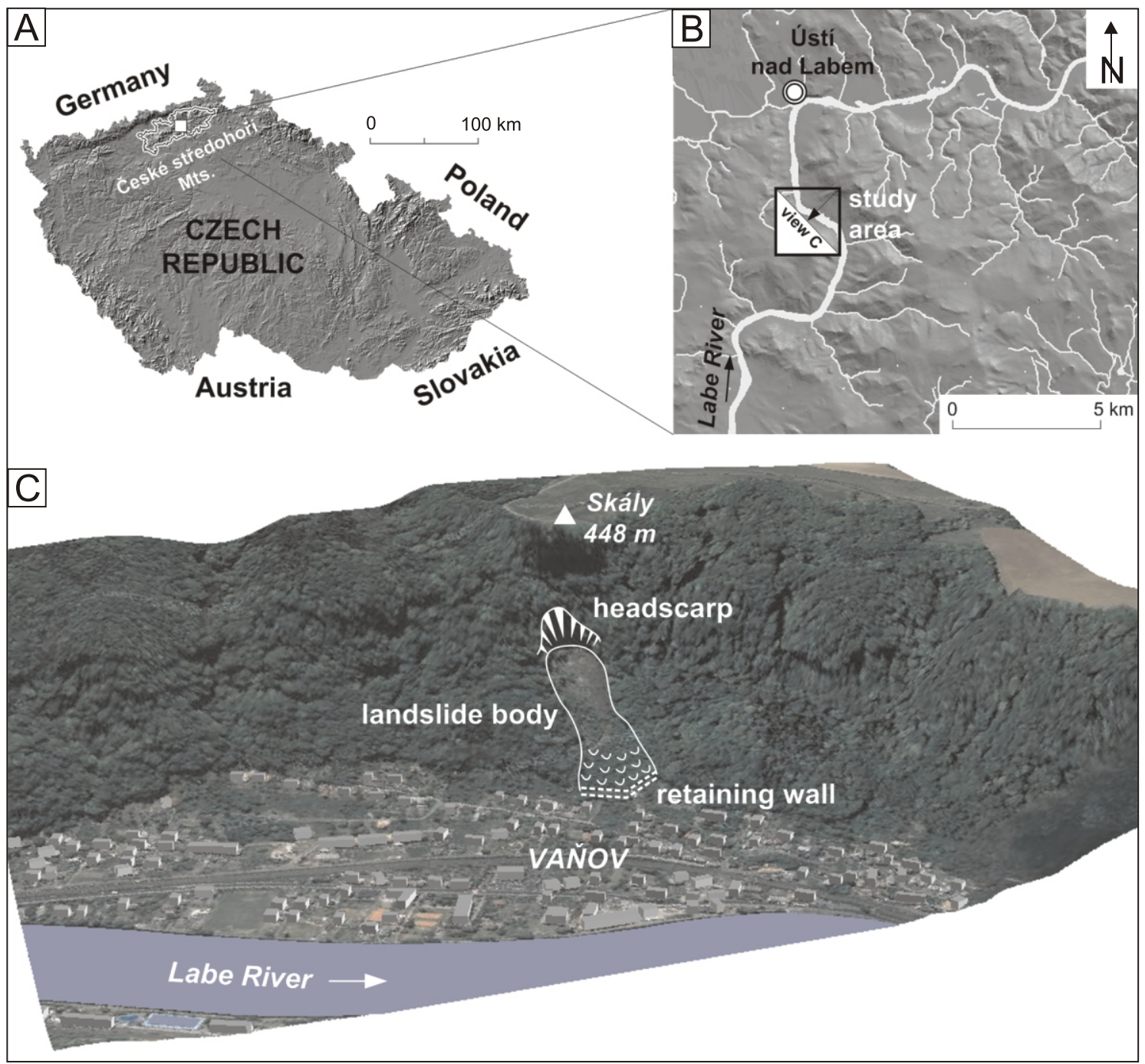

Fig. 1. Location of the recent Čertovka landslide

A - České středohoři Mts. within the Czech Republic; B - study area within the České středohoři Mts.; C - NE view on the Čertovka landslide; study area delimits wider surroundings of the landslide, which was subjected to the study of structural setting

tion including the main landslide body and subsequent rockfall accumulations below the headscarp and flowslides (cf. Cruden and Varnes, 1996). In this paper, the slope deformation is referred to as a landslide. Regional historical archives do not provide any information about historical activity at the site, however, evidence of former activity exists for the neighbouring parts of the study area (Raška et al., 2013). The landslide activity was first observed by local inhabitants in autumn 1994, and the major movement was monitored during the first months of 1995 (Cajz et al., 1995). The landslide activity and its propagation towards the residential quarter of Vaňov and towards the transportation infrastructure resulted in a detailed monitoring of the landslide (Kurka et al., 1995; Stemberk and Novotný, 1996) and finally in the construction of a retaining wall. The main results of the above mentioned works are a geomorphological map of the landslide and its near surroundings, monitoring of the landslide activity and analyses of landslide-triggering factors (primarily precipitation). Monitoring of the landslide kinematics continued in the following years (Sedlák and Glisníková, 2008). Although the mentioned works have pointed out some of the structural controls, a detailed study of structural setting of the landslide has not been conducted, and the structural background of the landslide remained unclear. Recently, a detailed geological mapping of the landslide was performed by Kycl et al. (2012), bringing new data on the lithological conditions at the headscarp of the landslide.

In the report on the state of the landslide site, Stemberk and Novotný (1996) concluded that the landslide might still be instable and that there is a possibility of further propagation of the scarp into the plateau above. Namely, the findings of these authors included depressions near the rim of the plateau, which might be considered a consequence of developing discontinuity planes parallel to the steep scarp under the Skály point (448 m a.s.l.; sometimes called Skalky or Vaňovská skála). These authors also recommended that the presence of these new potential discontinuities is studied using geophysical methods.

Structural settings of landslides have been studied by various approaches and techniques, including tectonic analyses (Scheidegger, 1998), analyses of bedding planes also implemented to regional models (Meentemeyer and Moody, 2000; 
Grelle et al., 2011), considerations on interactions between topography and bedding planes (Roering et al., 2005), in situ methods, such as Geological Strength Index (GSI; Marinos and Hoek, 2000) and intact strength measurements (Borrelli et al., 2006) as well as laboratory methods (ISRM, 1978; ASTM, 1987). In the Czech Republic, much of the research on structural setting of landslides and slope evolution has been carried out in the border mountain ranges (e.g., Klimeš, 2002; Margielewski, 2006; Hartvich and Mentlík, 2010; Pánek et al., 2011), employing both lithological analyses and geophysical surveys. Research within the LRV as yet focused on basic geological controls of various landslides (e.g., Suchý, 2000). A limited number of studies from the LRV have been, however, devoted to the implementation of new findings from geological mapping and morphotectonic analyses (Cajz and Valečka, 2010) to the landslide studies. The local and regional structural settings of individual landslides are, therefore, still subject to lively debate.

In this paper, we present the results of research focused on the structural setting of the Čertovka landslide, performed during the year 2012. The particular aim of the study is to evaluate the controlling factors of the Čertovka landslide based on integration of data from geological survey and morphotectonic analysis with the results of field structural-geomorphological analyses and geophysical sounding.

\section{METHODS}

\section{GEOLOGICAL MAPPING AND MORPHOSTRUCTURAL ANALYSIS}

Morphotectonic evaluation of the Čertovka landslide employed the results of Dužár et al. (2012) who applied various morphometric analyses in GIS (Geographic Information Systems) to assess the positions and activity of faults interpreted from the observed distribution of lithostratigraphic units (Cajz and Valečka, 2010).

The fundamental part of the morphostructural analysis was the detailed geomorphological mapping of the landslide (1:5000) and general geomorphological mapping of its surroundings $(1: 10,000)$. The input data for field survey included orthorectified aerial photos of the area with the maximum resolution of up to $10 \mathrm{~cm}$ per pixel (year 2010) and a point cloud elevation data from airborne laser scanning (ALS) with a density of 1 point per $5 \mathrm{~m}$ (data acquired from Czech Office of Surveying, Mapping and Cadastre, Prague). The DTM (digital terrain model) and maps of basic morphometric characteristics were created from point cloud data in ArcGIS 10 (ESRI) as a basis for field survey.

Following the geomorphological mapping, we performed structural in situ measurements and analyses. Disintegration of the rock and its possible relation to local and regional lithological and tectonic conditions were studied by measurements of orientations of joints and other planar features. Tectonic measurements were taken using a Freiberg geological compass. Fault-slip data were evaluated using the ROCK program (Málek et al., 1991) and plotted in tectonic diagrams. Differences in the susceptibility to rock weathering and disintegration of major lithologies of the landslide were measured as an intact strength of the rock outcrops using a Schmidt hammer (Goudie, 2006). Finally, the local tendency to surface rock disintegration was evaluated by the Geological Strength Index (GSI; Hoek and Brown, 1997; Marinos and Hoek, 2000), which establishes the degree of susceptibility to rock disintegration by assessing its surface and structural conditions on a visual basis.
Although there exist more complex classifications of rock mass strength (e.g., Selby, 1980; Synowiec, 1999; see Pantelidis, 2009 for review), their application under the local conditions of the study area is limited by steep and inaccessible terrain that does not enable to gain values for all parameters. Therefore, we decided to use the GSI as a simple tool supplementing the Schmidt hammer measurement, even though GSI is not primarily designed for structurally controlled failures.

The above mentioned measurements were carried out both at the Čertovka landslide headscarp and at two comparative landslide sites near the Čertovka landslide (numbers 2 and 3 in Figs. 2-4).

\section{ELECTRICAL RESISTIVITY TOMOGRAPHY}

Electrical resistivity tomography (ERT) is generally considered the most suitable geophysical technique for the studied problem. It has been successfully applied in numerous landslide and structural studies (e.g., Apparao and Roy, 1973; Schrott and Sass, 2008; Hartvich and Valenta, 2011; Pánek et al., 2011). As the most advanced among the DC (direct current) resistivity methods, ERT enables a $2 \mathrm{D}$ mapping of resistivity in cross-sections over $1 \mathrm{~km}$ long with a depth reach over $100 \mathrm{~m}$.

In order to answer the questions raised by Stemberk and Novotny (1996), concerning the depth of the sliding plane, tectonic control of the landslide and its possible future propagation further into the plateau, we measured two ERT profiles: one along the slope deformation axis, and the other perpendicular to the axis across the centre of the landslide body (Fig. 3B).

The longitudinal profile runs along the axis of the slope deformation, starting $160 \mathrm{~m}$ far on the plateau. This was necessary to reach appropriate depth near the rim of the plateau. The course of the profile followed extremely difficult field conditions, as its central part descended by $>100 \mathrm{~m}$ at a length of $100 \mathrm{~m}$, and it was necessary to use full rock-climbing equipment to set up the ERT profile. A standard Wenner-Schlumberger array was used, with an electrode step of $5 \mathrm{~m}$, and the total number of electrodes was 96 . The Wenner-Schlumberger array was selected as it yields generally balanced results depicting both horizontal and vertical structures (Loke, 2010), which was needed to observe the inner composition of the landslide body together with the orientations and positions of volcanic bodies (Skácelová et al., 2010). Total surface length of the profile reached $475 \mathrm{~m}$, the horizontal length was only $385 \mathrm{~m}$ (cf. Fig. 7). This wide difference was due to the high altitude span of $>200 \mathrm{~m}$.

The transverse profile crossed the longitudinal one at station $440 \mathrm{~m}$, and was measured across the main landslide body approximately $100 \mathrm{~m}$ from the scarp. The profile is $195 \mathrm{~m}$ long (on the surface; its horizontal length is $190 \mathrm{~m}$ ), and the studied landslide is situated between stations 100 and $175 \mathrm{~m}$, and crosses the longitudinal profile at station $135 \mathrm{~m}$. This profile was also measured using the Wenner-Schlumberger array, and included 40 electrodes with $5 \mathrm{~m}$ stepping.

The measured datasets were inverted using the Res2DInv software by Geotomo.

\section{GEOLOGICAL SETTING}

The Čertovka landslide is located in the left slope of the LRV, $5 \mathrm{~km}$ south of the centre of Ústí nad Labem (Fig. 1). The whole area belongs to the České středohoři Mts. neovolcanic range. The LRV represents a natural axis of this range. While the general orientation of the valley is $\mathrm{N}-\mathrm{S}$, it is locally modified by the presence of structurally predisposed meanders. The 


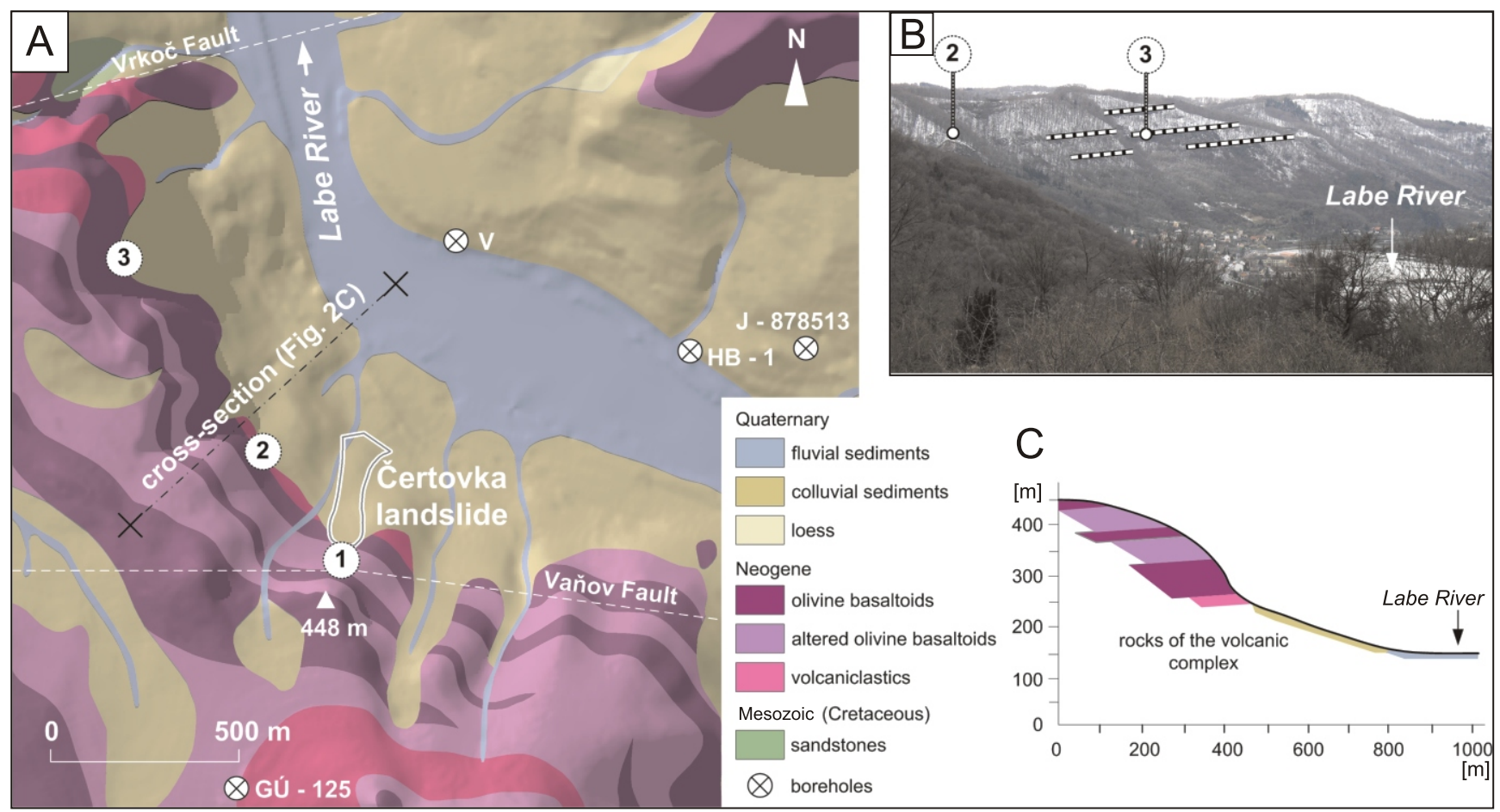

Fig. 2A - simplified geological map of the study area (after Šebesta, 1997, modified); B - left-bank slope of the Labe River valley, dotted lines emphasize structural levels composed of olivine basalts, numbers in circles represent comparative sites of older landslides; C - geological cross-section (for location see Fig. 2A)
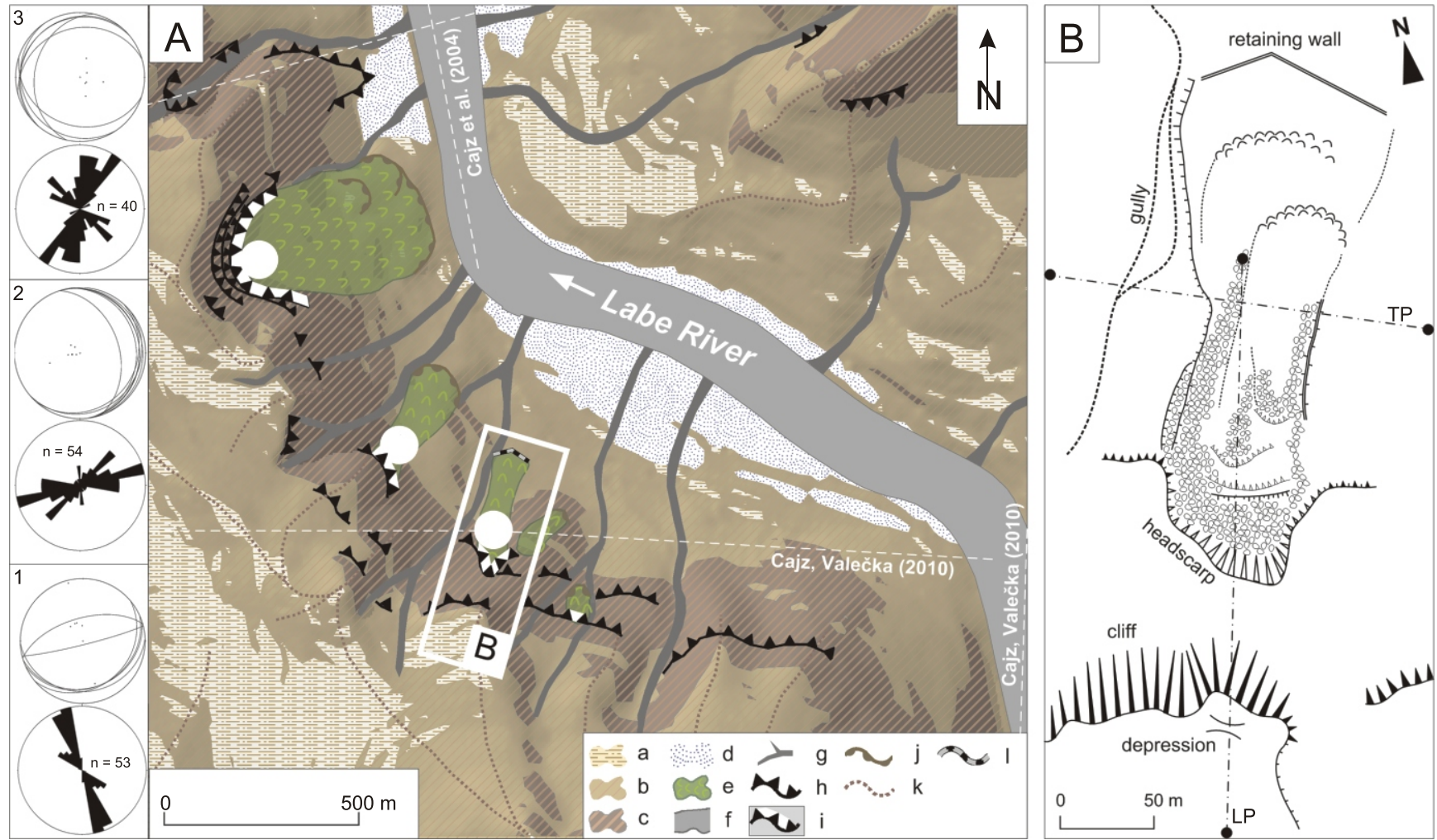

Fig. 3A - geomorphological sketch of the study area with the main structural features; B - detailed geomorphological sketch of the Čertovka landslide

a - gently inclined slope and denudation level, b - erosional slope, $c$ - steep erosional slope, $d$ - terrace of fluvial deposits, e - landslide, $f$ river channel, $\mathrm{g}$ - V-shaped valley and gully, $\mathrm{h}$ - cliff, $\mathrm{i}$ - landslide headscarp, $\mathrm{j}$ - landslide toe, $\mathrm{k}$ - main ridges, $\mathrm{I}$ - retaining wall; diagrams of bedding planes (lower hemisphere projection, equal area) and orientation of main joints $\left(10^{\circ}\right.$ classes) on the left refer to the numbers of localities in the map (Fig. 2A); white lines indicate faults identified in previous studies; LP - longitudinal ERT profile, TP - transverse ERT profile 


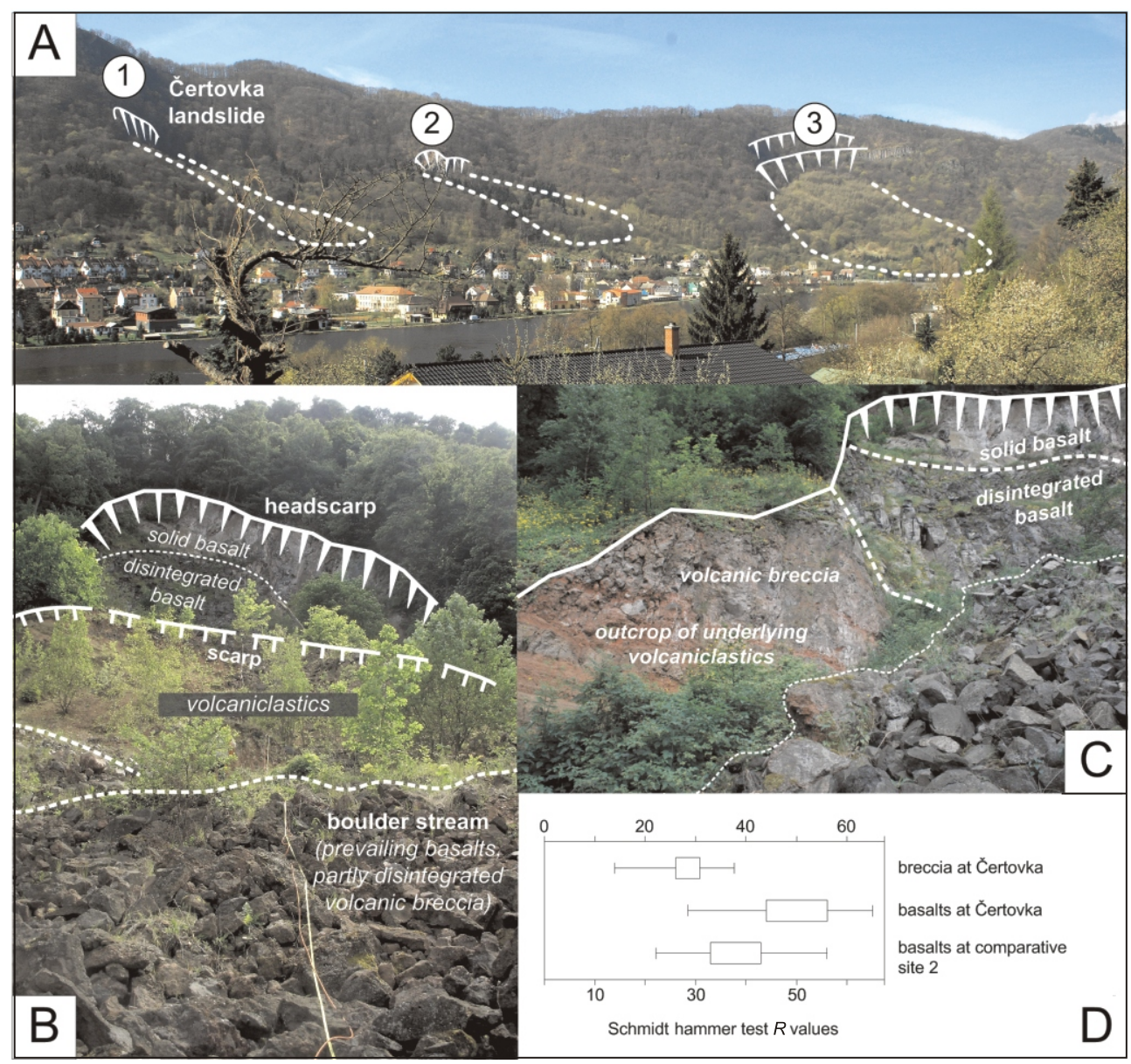

Fig. 4A - panoramic view of the Čertovka landslide and two comparative landslide sites indicating headscarps and extent of landslide bodies; B - uppermost segment of the Čertovka landslide; C - lithological boundary between basalts and volcaniclastics at the headscarp; D results of in situ Schmidt hammer intact strength test at the headscarp of the Čertovka landslide and comparative site 2

headscarp of the recent landslide is located at the elevation of $355 \mathrm{~m}$ and its toe at ca. $180 \mathrm{~m}$, which is approximately $40 \mathrm{~m}$ above the LRV bottom. Above the landslide headscarp, the valley slope continues upward to the elevation of $448 \mathrm{~m}$, first as a steep slope with inclination exceeding $30^{\circ}$, and later breaking into a partly disintegrated cliff, $50 \mathrm{~m}$ high. The width of the landslide varies between 70 and $120 \mathrm{~m}$. The length of the landslide is $320 \mathrm{~m}$ and its toe reaches the uppermost parts of the residential quarter of Vaňov.

The study site is situated in the Ústí Formation (sensu Cajz, 2000) rocks, the lowermost part of the České středohorri Mts. Volcanic Complex. These rocks belong to the group of olivine basaltoids and vary from alkaline olivine basalt to olivine nephelinite, with a majority around the central member - nepheline basanite. A broad range of consistencies is observed, from fresh basalts to highly altered material, and from solid jointed basalts to nearly loose volcaniclastics. These differences follow from the variety of depositional conditions at the time of the Ústí Formation volcanic activity and the subsequent tectonic development. The Ústí Formation volcanic products filled mainly a large depression situated in the central part of the present-day mountain range as a part of the Ohře/Eger Rift. This complicated depression resulted from long-lasting tectonic activity and subsided synchronously with volcanic activity. The faults in the graben interior are organized into a tectonic plan of irregular rhomboidal blocks (Cajz et al., 2004; Cajz and Valečka, 2010), with high vertical tectonic differentiation between the blocks.

This depression was filled with water (lakes, peat-bogs, less commonly streams). The contact of hot lava with water resulted in the generation of a large volume of volcaniclastic material, although the volcanic activity was prevalently effusive. Less frequent explosive activity of phreatic/phreatomagmatic or subaquatic type created pyroclastics, but they are hardly detectable now due to the highly probable early postgenetic sedimentary process in the aquatic environment. Clearly recognizable are only pyroclastics of mostly magmatic type, which originated in subaerial conditions, either outside the sedimentary basin or at emerged places mostly in the upper part of the Ústí Formation. The emergence of some parts inside the large depression above the water level was caused by accumulation of volcanic material near the vents, by a syngenetic tectonic uplift, and by a combination of both. The vent responsible for the production of majority of volcanic material at the study site can be seen NW of Vaňov in the area of Větruše-Újezd-Hostovice-Vrkoč. Subaerial conditions of volcanic activity during the formation of the upper preserved rocks - the emergence of volcanic material above the water reservoir and thus a transition between the Surtseyan and Strombolian eruption type - are known from pyroclastics documented during the last detailed geological mapping near Větruše (Čech, 1991). They were de- 
tected in the upper part of the Čertovka headscarp as well (Kycl et al., 2012).

The Vaňov Fault transects the Čertovka landslide profile at, and above, its headscarp. Its principal fault plane probably coincides with the prominent scarp of Skály (448 $\mathrm{m}$ a.s.l.). It was defined by Cajz et al. (2004) based on field survey, borehole data and fault-slip measurements, and later re-defined by Cajz and Valečka (2010). It strikes ENE-WSW at Vaňov but bends towards the $\mathrm{W}$, as indicated by a subtle step in topography south of Podlešín (ČÚZK, 2013) and by its verified continuation at Stadice in the Bílina River valley (Cajz and Valečka, 2010). Steep northern dip of the principal fault plane can be inferred from the measured orientations of minor faults.

A complex history of movements along the Vaňov Fault can be deduced from the stratigraphic units encountered in boreholes. An uplift of the $\mathrm{N}$ block by tens or a few hundreds of metres must have occurred between the deposition of the Merboltice Formation (Santonian, $85 \mathrm{Ma}$ ) and the onset of basaltic tuff deposition (Ústí Formation, $36 \mathrm{Ma}$ ), as indicated by complete erosion of the Merboltice Formation sandstones/subarkoses in the north. This movement can be attributed to some of the compressional stress fields of phase $\alpha$ (Adamovič and Coubal, 1999; Ulrych et al., 2011).

A relative subsidence of the northern block by ca. $100 \mathrm{~m}$ after the deposition of the basal members of the volcanic complex of the České středohoří Mts. is evidenced by the differences in the elevations of the base of the volcanic complex at Vaňov in the following boreholes: V (120.2 m a.s.I.), HB - 1 (116.6 $\mathrm{m}$ a.s.l.) and $\mathrm{J}-878513$ (130.9 $\mathrm{m}$ a.s.I.) in the north, and GÚ - 125 (205.5 m a.s.I.) in the south. Given the fault geometry, relation of these movements with the Oligocene to Miocene tensional stress fields within phase $\beta$ seems probable (Adamovič and Coubal, 1999). A combination of fault movements in phases $\alpha$ and $\beta$ resulted in the present-day contrasting position of Cretaceous rocks along the fault. In the south, the Merboltice Formation sandstones form outcrops in the lower levels of slopes on both banks of the Labe River, while in the north, the top of the Cretaceous sediments represented by the Brezno Formation lies below the Labe River channel, and the valley slopes are composed of rocks of the volcanic complex of the České středohoři Mts. The latter setting applies to the site of the Čertovka landslide.

Right-lateral strike-slip movements were previously observed on minor $\mathrm{N}$-dipping fault planes within the Vaňov Fault Zone (Cajz et al., 2004), indicating a reactivation of the zone by transcurrent movements tentatively attributed to Late Miocene compressional phases $\gamma \delta$ of Adamovič and Coubal (1999).

\section{RESULTS}

\section{GEOLOGY AND GEOMORPHOLOGY OF THE SITE}

The headscarp of the Čertovka landslide is developed in basaltic volcanics and volcaniclastics of the Ústí Formation sensu Cajz (2000), Figures 2A and 4C (see Kycl et al., 2012 for details). The base of the volcanic complex at the Čertovka landslide and two other comparative sites is situated approximately 20-30 m below the Labe River level. This fact, and the rock cropping out at the headscarps (see Kycl et al., 2012 for details), proves that the initiation of the landslide occurred inside the rocks of the volcanic complex themselves. It is different from many other sites of landslides in the České středohoří Mts. (cf. Burda et al., 1998; Rybář et al., 2000b; and unpublished reports of the ISPROFIN research), where the underlying Cretaceous rocks are involved. In the case of the three locations discussed in this paper, the reddish well-stratified body (see Figs. $2 \mathrm{~A}$ and $4 \mathrm{C}$ ) of volcaniclastics seems to be very important. This is a volcanogenic sediment, originated by syngenetic re-washing of finest material produced during hyaloclastic disintegration of subaquatic lavas. The material consists principally of clay-, silt- and sand-sized particles. Anyway, larger clasts are very often totally argillized basaltic fragments, making the content of clay minerals enormous in this rock type.

The left-bank area of the LRV is composed of two genetically different topographic units divided by a steep erosional slope segment (Fig. 3A). The lowest area along the Labe River is represented by flat surface of Late Pleistocene fluvial terraces, which are currently intensely transformed by residential and technical infrastructure. The highest level preserved in the SW part of the study area represents the relics of a denudation surface that formed after the end of Neogene volcanic activity (Král, 1966). The $300 \mathrm{~m}$ elevation difference between these two levels approximately indicates the depth of erosion of the Labe River during the Pliocene-Pleistocene period (cf. Balatka and Kalvoda, 1995); however, the area was affected by post-volcanic differential tectonic movements (Cajz and Valečka, 2010) and the above mentioned overall erosion of the Labe River is to be considered rather indicative. The steep erosional slope segment forms a continual strip at the elevation of $180-400 \mathrm{~m}$. Its characteristic feature is step-like morphology formed by alternating steep slopes and cliffs predisposed by the presence of less resistant volcaniclastics and volcanic breccias, and by outcrops of solid basaltic rocks, respectively (Fig. 2B). We identified three preserved structural levels of basaltic rocks forming the cliffs in different stages of disintegration. The continuity of structural levels is interrupted by headward erosion of permanent and ephemeral streams forming $\mathrm{V}$-shaped valleys and gullies. The crossings of $\mathrm{V}$-shaped valleys and gullies resulted in the evolution of frequent lithologically predisposed knickzones (Dužár et al., 2012).

Morphologically notable landslides on the left-bank slopes of the LRV are located in the lower part of the steep erosional slope (Fig. 4A), with the headscarps evolved at the lower preserved structural levels. The only exception is the largest and, according to old maps (dating has not been performed yet), also the oldest landslide (comparative site 3 in Figs. 2 and 4) with the headscarp spread across two structural levels and partly reaching the third one. The base of the headscarp of the Čertovka landslide is situated at the contact zone between solid basalts and volcanic breccias and volcaniclastics (Fig. 4C), which is similar to comparative site 2 . The performed intact strength measurements using the Schmidt hammer (Fig. 4D) confirm significant differences between rock strength of the two lithological units. The measurement indicates, however, that the intact strength of the solid basalts decreases significantly at older landslides (comparative site 2).

The topography of the Čertovka landslide can be divided into three segments (Fig. 3B):

- in the uppermost segment, the landslide body below the main headscarp is formed by thick accumulation of basaltic blocks. The end of the accumulation is inclined against the slope forming a shallow trench, and then continues with a scarp to the middle landslide segment (Fig. 4B); 
- the middle segment has a step-like morphology formed by scarps of younger landslides and flowslides. Boulder streams below scarps of these landslides and flowslides pass into a complex accumulation of basaltic boulders and disintegrated volcaniclastics and breccia infills in their transportation segment. The NW side of the landslide segment is represented by a boulder stream continuing from the uppermost landslide segment. In this respect, the Čertovka landslide represents a complex slope deformation rather than an individual landslide;

- the terminal segment of the Čertovka landslide has a slightly inclined, uniform morphology formed by the accumulation surface of the toe of younger landslides. The major landslide toe is transformed by a counter-slope retaining wall, which modified its former morphology (cf. Stemberk and Novotný, 1996). The margins of the landslide are characterized by lateral levees. The NW margin of the landslide toe is exposed up to the height of $4 \mathrm{~m}$ by an erosional gully.

\section{TECTONIC MEASUREMENTS}

The dominant joint strike at the Čertovka headscarp is NNW-SSE. Bedding planes are inclined gently against the slope $\left(20-25^{\circ}\right)$, forming an anaclinal slope. Secondary planes, representing the sliding surface, dip steeply (generally $60-85^{\circ}$ ) to the $\mathrm{N}$. The headscarp of comparative landslide site 2 is less disintegrated and enabled only the measurement in its lowest part. The prevailing joint strike is $\mathrm{W}-\mathrm{E}$. The character of the headscarp did not enable to clearly identify the bedding planes. The planar features at the headscarp, representing the sliding surface, dip $\mathrm{E}$ at medium angles $\left(\max .40^{\circ}\right.$ ), but the dip angle is much steeper in the upper parts of the headscarp according to remote observation. The headscarp of comparative landslide site 3 was more complex in respect of its extent and lithological conditions than the two previous sites. The joint orientation indicates prevailing NNE-SSW strikes, and the bedding planes dip anaclinally SW and NW at an angle of $10-30^{\circ}$. The reliability of the dataset from comparative site 3 is limited, however, be- cause the representativeness of measurements is low due to difficult access to higher structural levels of the headscarp.

The headscarp of the Čertovka landslide is represented by a fault plane with two generations of striae. Fractures of the main system dip N (rarely SW) at steep angles of $76-87^{\circ}$. They host an older generation of fine striae plunging NW at angles of $65-76^{\circ}$ with an indeterminable sense of movement (Fig. 5A). The striae are developed in mylonitized volcanic rocks or in Fe-oxyhydroxide fillings of fractures. Splay fractures to the main system dip steeply ENE, and are of transtensional character, with less distinct striae but with fills consisting of sand-sized material and volcanic rock fragments.

Besides steep fine striae, fractures of the main system host a younger generation of coarse striae developed on slickensides of a white non-carbonate mineral, probably quartz (Fig. 5B). This set of striae is best developed on fractures dipping $\mathrm{N}$ to $\mathrm{NW}$ at angles of $78-85^{\circ}$, and clearly differs from the older set in its subhorizontal plunges $\left(<13^{\circ}\right.$ to the ENE or WSW). These striae show a right-lateral movement of blocks and clearly overprint the steep older-generation striae. Tectonic diagrams showing planes with the two generations of striae are shown in Figure 6.

\section{INTERNAL STRUCTURE OF LANDSLIDE}

Longitudinal profile. Despite the terrain difficulty and initial problems with the electrode grounding, the longitudinal profile yielded valuable data. Figure 7 shows the 5 th iteration of the dataset. Flat surface of the plateau (first $150 \mathrm{~m}$ ) is formed by rather compact basaltic rock (high resistivity around $4000-8000 \Omega \mathrm{m}$ ), overlain by weathered rock and soil, max. $5 \mathrm{~m}$ thick (around $100 \Omega \mathrm{m}$ ). The most interesting feature on the plateau is a sharply limited zone of very low resistivity (around $10 \Omega \mathrm{m}$ ), parallel to the slope and situated approximately $15-20 \mathrm{~m}$ from the plateau rim. It seems to continue parallel to the surface along the steep cliff (150-175 m). Approximately $70 \mathrm{~m}$ long less-inclined middle section of the slope is still within the basaltic layer according to the resistivity values.

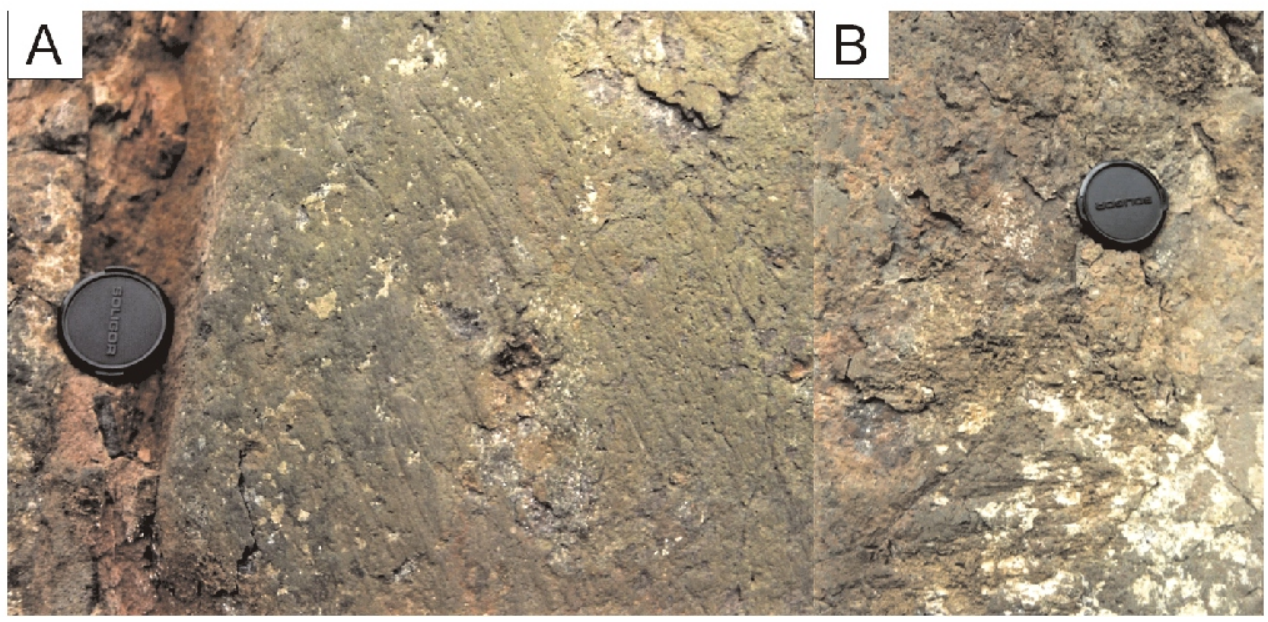

Fig. 5A - the older generation of fine striae on steep N-dipping fractures, WNW on the right; $B$ - the younger generation of coarse, subhorizontal striae in slickensides of a white mineral on steep N-dipping fractures, WNW on the right 

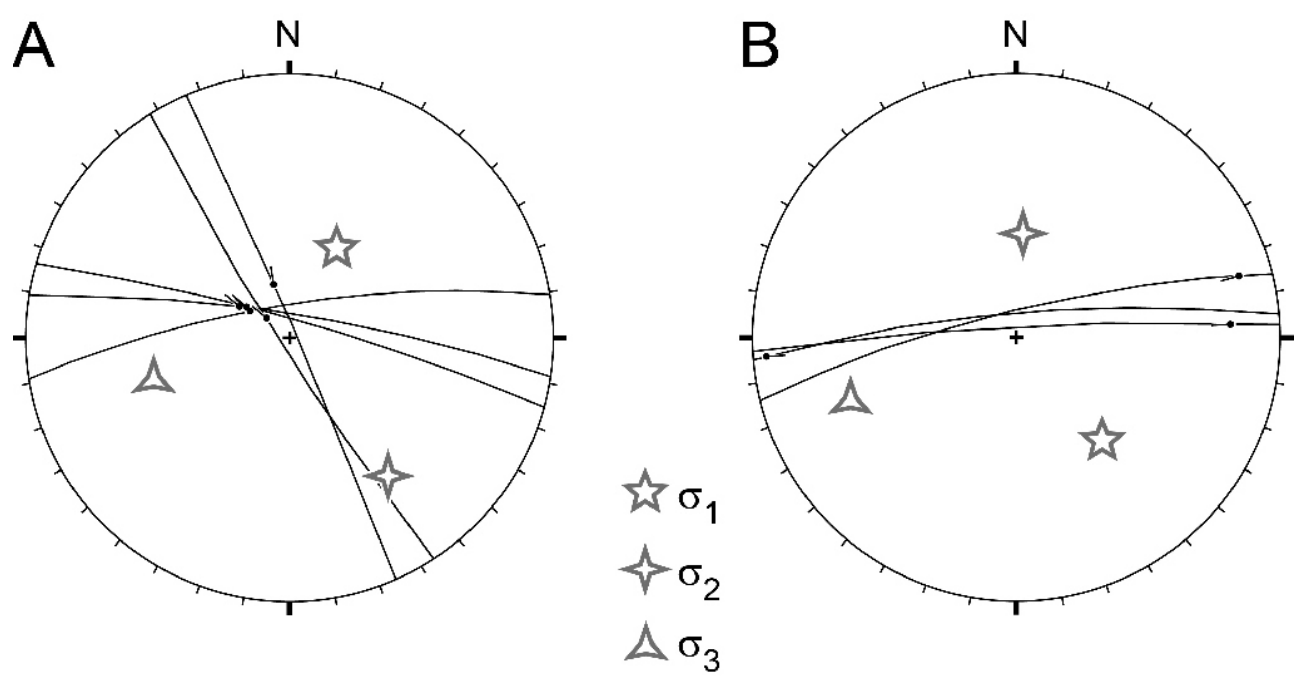

Fig. 6. Tectonic diagrams of striated fault planes measured on the headscarp of the Čertovka landslide (lower hemisphere projection)

A - planes with the older generation of fine striae; B - planes with the younger generation of coarse, subhorizontal striae; $\sigma_{1}$ - maximum compressive stress vector, $\sigma_{3}-$ minimum compressive stress vector

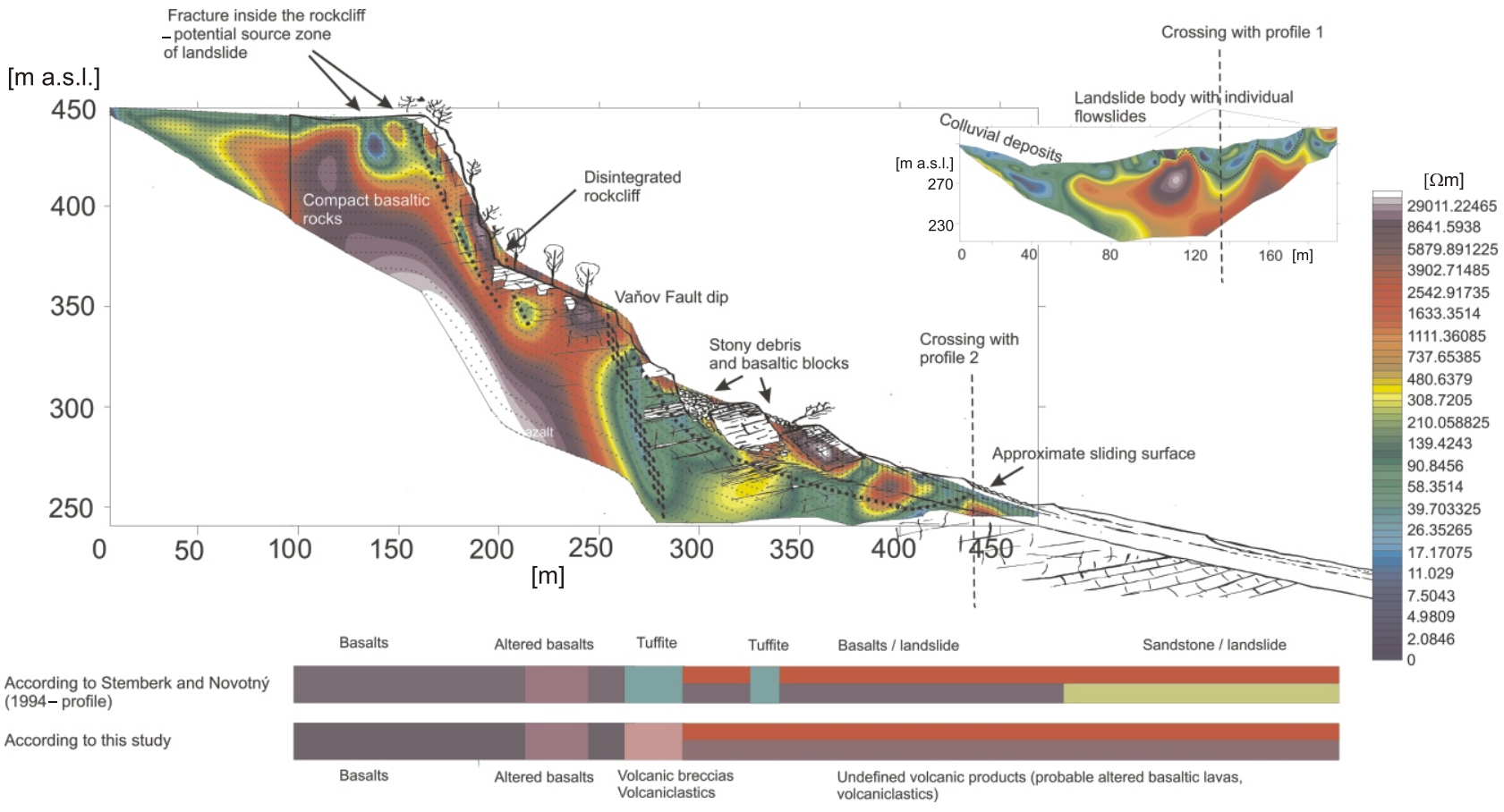

Fig. 7. Longitudinal and transverse profiles of the ERT measurement

Sketch of the longitudinal profile after Stemberk and Novotný (1996); compare the original geological interpretation with the geological setting described in this study 
The main scarp of the Čertovka landslide, $30 \mathrm{~m}$ high, lies at $230 \mathrm{~m}$ of the profile. There is clear indication of a low-resistivity $(20-100 \Omega m)$ zone continuing along the scarp and further into the bedrock. Similar features are typical for crossing a sub-vertical tectonic line, usually a fault (Burda et al., 2013; Hartvich and Valenta, 2013).

The body of the landslide $(230-375 \mathrm{~m})$ is clearly observable in the profile. Blocks of basaltic rock of various sizes are on the surface, and the sliding plane can be identified as a lower-resistivity zone at a depth of approximately $20 \mathrm{~m}$.

The underlying volcanic products (probably volcaniclastics or altered basaltic lavas), inclined at a moderate angle against the slope, can be observed in the lowermost part of the profile. These rocks show lower resistivity values $(20-150 \Omega \mathrm{m})$ due to the presence of clay.

Transverse profile. The transverse profile, which reached a lower depth (approx. $40 \mathrm{~m}$ ), clearly features several phenomena:

- three shallower lobes of a distal part of flow-like landslide, which correspond to the youngest reactivations of the landslide movements (Fig. 7), max. $15 \mathrm{~m}$ deep. These are formed by low-resistivity (10-100 $\Omega \mathrm{m})$ volcaniclastic material;

- large blocks of rotated volcanic blocks, forming "islands" between the flow lobes, with resistivities of $1200-10,000 \Omega \mathrm{m}$. Even higher resistivity values can be attributed to open crevasses between blocks;

- underlying volcanic products, more prominent in the northern end of the profile, with low resistivities of 20-150 $\Omega m$.

\section{DISCUSSION}

\section{STRUCTURAL SETTING OF THE ČERTOVKA LANDSLIDE}

Lithological control of the Čertovka landslide has been supposed to be related to contact zones between lithological units of different strengths. Older regional geological maps and previous geotechnical reports about the landslide erroneously indicated that the sliding surface has probably evolved at the contact zone between solid basalts of the Ústí Formation and Santonian sediments of the Merboltice Formation (Kurka et al., 1997). This misinterpretation (also contained in the first report about the Čertovka landslide - Cajz et al., 1995) resulted from inaccurate geological maps available at that time, showing the base of volcanic complex several tens of metres higher. The initiation of the landslide was considered to be caused by disintegration of the basalt cliffs, resulting in rockfalls and increasing loading of the underlying less resistant sediments (Kurka et al., 1997), and by increasing water capacity in the underlying sediments due to high precipitation in 1993 (Stemberk and Novotný, 1996). Possible location of the sliding surface at the contact inside the volcanic complex was also discussed (Stemberk and Novotný, 1996). Kycl et al. (2012) studied the geological setting at the landslide headscarp in detail and newly concluded that the sliding surface developed inside the volcanic complex. In this respect, the Čertovka landslide parallels the nearby large Martinská stěna landslide at Čeřeniště, which was also founded along sliding surfaces within the volcanic complex, possibly along clay-rich volcanosedimentary intercalations (Cílek et al., 2000; Rybář et al., 2000b).

According to our results of field mapping and ERT profiling, the sliding surface in the headscarp area and upper segment of the landslide formed at the contact zone between solid basalts with their hyaloclastic breccias and clayey volcaniclastics with anaclinal bedding (redeposited fine material produced during a subaquatic effusion). Continuation of the sliding surface in the transportation and accumulation segment of the landslide is developed still inside volcanic rocks. Their lithology is not clear enough, due to the cover of sliding material. No borehole documentation is available. Volcaniclastics are highly probable but altered basaltic lavas cannot be excluded. The ERT also seems to confirm the backwards sloping layering of the underlying volcanic products. Lithological setting at the contact between solid basalts and volcanic breccias and volcaniclastics was also typical of comparative site 2. Topography at the base of the headscarp of comparative site 3 did not permit to identify outcrops of volcanic breccias and volcaniclastics; however, their local outcrops were found at the SW and S margin of the landslide. The results of intact strength measurements of volcanic breccias and solid basalts of the Ústí Formation indicate that the differences in strength of these lithological units are significant. This was also shown by the evaluation of the GSI (Marinos and Hoek, 2000) illustrated in Figure 8. Furthermore, both the intact strength measurement and GSI evaluation indicated that the basalts at the landslide headscarps are subject to intense disintegration after their exposure. The rapid disintegration of the headscarp and weathering of its surface in the period after the initiation of the landslide show a nonlinear progress of rock weathering (cf. Viles et al., 2007; Klimeš, 2009). The rapid disintegration and weathering of the headscarp results in frequent rockfalls at all studied landslide sites.

Taking into account the above mentioned results, the formerly considered initiation of the Čertovka landslide due to loading of the underlying material that was affected by precipitation may be still valid, even though the location of the sliding surface would be within the volcanic complex.

The lithostructural setting of the Čertovka landslide is schematically shown in Figure 9. The landslide evolved at the intersection of the Vaňov Fault with structures striking NNW-SSE. The effect of these structures was confirmed by morphotectonic analysis (Dužár et al., 2012). The influence of the Vaňov Fault is represented by the orientation of the major headscarp of the Čertovka landslide in the E-W direction and by the prevailing steep dip of the fractures at the headscarp and of the sliding surface to the $\mathrm{N}$. The joint orientation at the headscarp with prevailing NNW-SSE strikes corresponds to the LRV segment to the $\mathrm{N}$ of the landslide, being possibly influenced by the course of the Labe Fault (Cajz et al., 2004; Cajz and Valečka, 2010). Joints striking NW-SE should be interpreted rather as Riedel shears to the Vaňov Fault structures generated by their right-lateral strike-slip activation. Intense disintegration and loosening of the basalt rock cliff has been accelerated by activation of the joints perpendicular to the headscarp direction. Segmentation of the rock massif along subhorizontal planes was rendered by bedding planes and stratigraphic boundaries within the volcanosedimentary complex. Structural controls at the comparative sites 2 and 3 are different. While the joint orientation at the headscarp of comparative site 2 reflects the strike of the Vaňov Fault, the measurements of joint orientations at comparative site 3 yielded results which are not statistically significant.

The two generations of striae identified at the headscarp of the landslide are clearly of tectonic origin, and not generated by the mass movement, as suggested by their plunge angles different from vertical. They document tectonic movements on minor faults subsidiary to the principal fault plane of the Vaňov Fault, which probably runs further upslope. Kinematics of the tectonic movements corresponds well with the geological assumptions. In this respect, the older-generation striae (although of indefinite 


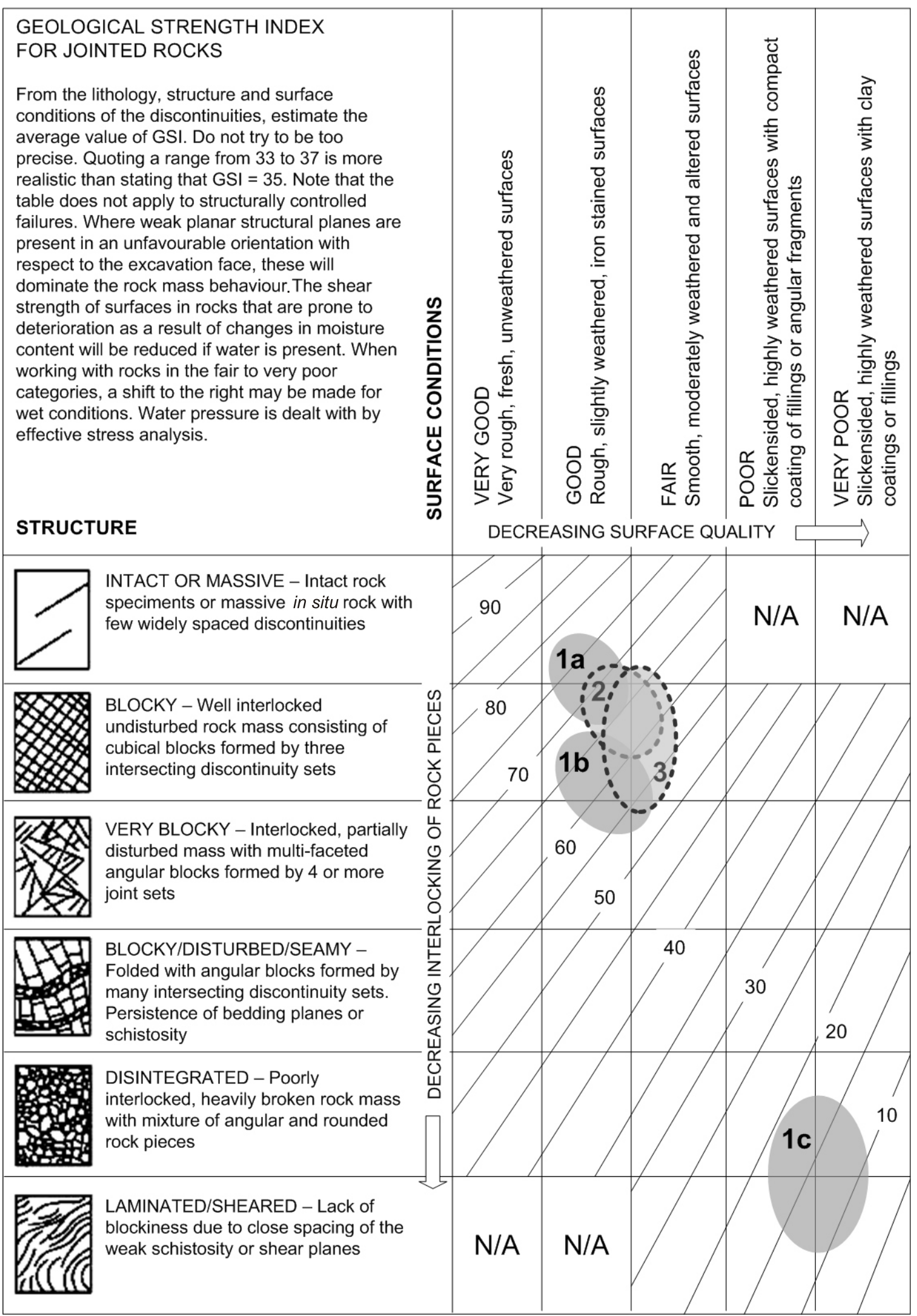

Fig. 8. Geological Strength Index (GSI) for the lithological units at the Čertovka landslide and comparative sites (the GSI sheet after Marinos and Hoek, 2000)

Numbers stand for the study sites (Fig. 2); note to the study site 1: $a$ - solid basalt, $b$ - disintegrated basalt, c - volcanic breccia (see Fig. 4B, C); N/A - not analysed 


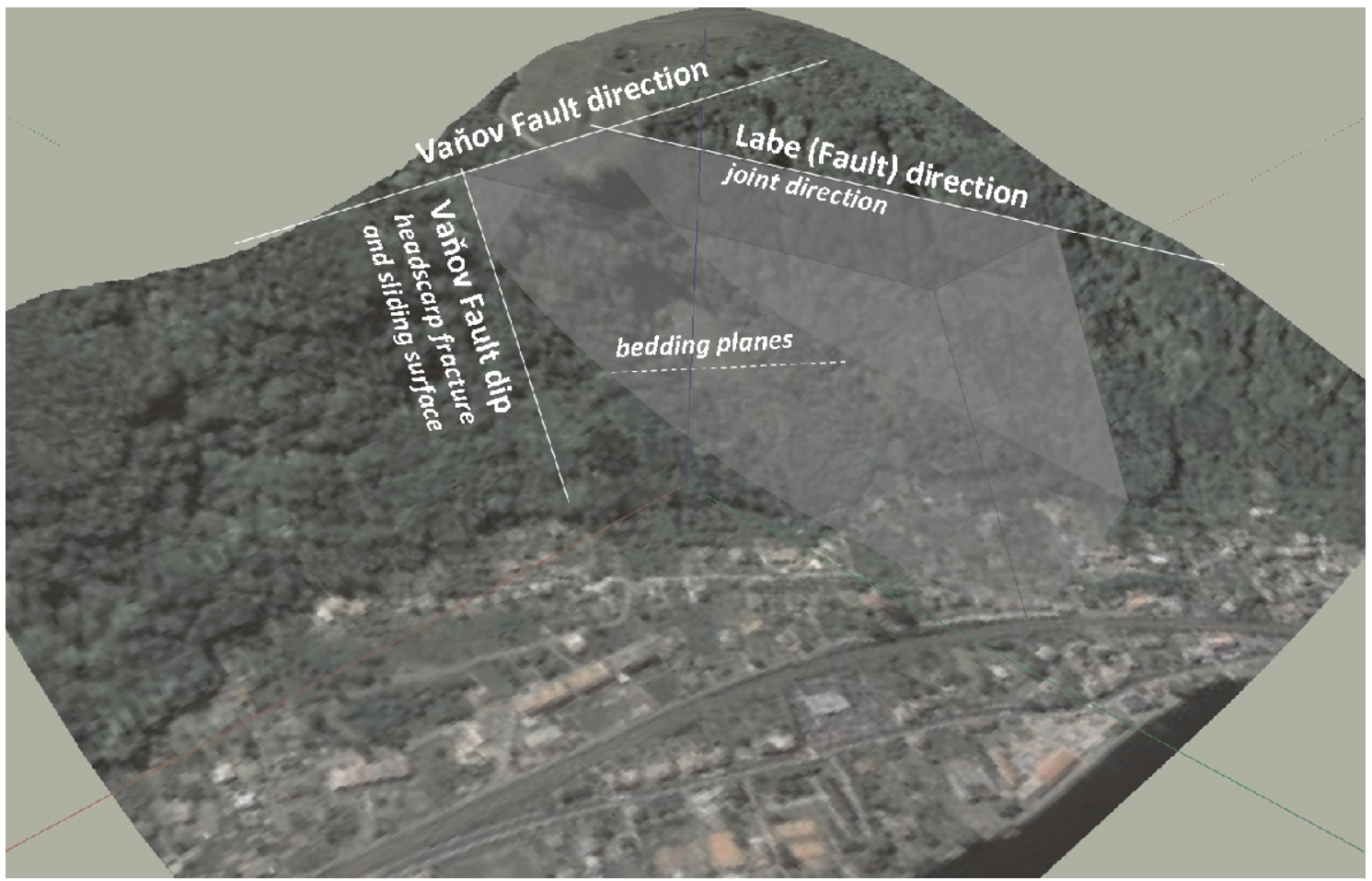

Fig. 9. General lithostructural setting of the Čertovka landslide headscarp

sense of movement) probably reflect the subsidence of the northern block after the deposition of the basal members of the volcanic complex of the České středohoři Mts. They suggest that the dip-slip component on $\mathrm{N}$-dipping faults was accompanied by a subordinate left-lateral strike-slip component, indicating a NW-SE extension. Although the origin of these striae under a compressional stress cannot be excluded, it seems to be contradicted by the tensional character of splay structures. The stress field responsible for these striae can be therefore tentatively attributed to phase $\beta$ of Adamovič and Coubal (1999), specifically to its culmination by NW-SE extension at 24-16 Ma. The origin of younger-generation striae is compatible with a NW-SE compression within phase $\delta$ in the Late Miocene to ?Pliocene at 10-5 Ma (Adamovič and Coubal, 1999).

Weakening of the rock massif by the identified deformations along the Vaňov Fault Zone together with disintegration of the massif along the joints perpendicular to the Vaňov Fault are the main pre-requisite for mass movements at the Čertovka site. The favourable factors for gravitational disintegration include: (1) the high density of fractures resulting from repeated fault activation, (2) the favourable orientations of fractures thus formed, (3) a decrease in shear friction on the fault planes caused particularly by their smoothing by strike-slip movements and slickenside formation.

FUTURE ACTIVITY OF THE ČERTOVKA LANDSLIDE AND EVOLUTION OF THE SITE

The slope profile at the Čertovka landslide site has two major structural levels composed of solid basalts interspersed with volcaniclastic material and forming a cliff at the top of the slope and the headscarp of the Čertovka landslide in the central segment of the slope profile. In agreement with Stemberk and Novotný (1996), our results indicate that the reconstruction of slope dynamics and evaluation of its future development re- quires accentuating the interaction between these two structural levels. The longitudinal ERT profile brought crucial information on the inner structure of the slope. It indicated rather clearly the position of the potential plane of discontinuity, which was predicted by Stemberk and Novotný (1996). In their study, the possible discontinuity plane was deduced from a shallow depression in the plateau above the higher situated cliff. The ERT profiles showed two such inhomogeneities, which are observable as far as $30 \mathrm{~m}$ into the plateau, forming two approximately parallel planes. These discontinuities are parallel to the Čertovka landslide headscarp. Both these discontinuities and the fractures at the headscarp are predisposed by the Vaňov Fault (Fig. 10A, B) and its kinematics. At the same time, the rock massif was disintegrated due to jointing parallel to the Labe River. Rockfalls of basaltic blocks are controlled by intersections of faults and fractures parallel to the Vaňov Fault and joints parallel to the Labe River direction.

Considering the local tectonic deformations predisposing the rock massif disintegration and the lithological setting at the contact between basalts, breccias and volcaniclastics as the main controlling factors for the sliding surface initiation, we may suggest a hypothetical future evolution of the slope, which is described schematically in Figure 10. Structural features indicated by dashed lines in the figure are based upon the results of ERT profiling, field survey and structural measurements. In the first stage (Fig. 10C), the cliff in the upper part of the slope and the headscarp of the Čertovka landslide in the middle segment are apparent. The red arrows indicate the movement predisposed by discontinuities in the cliff as identified by ERT profile. Meanwhile, the headscarp of the Čertovka is subject to rapid disintegration predisposed by jointing and surface weathering as shown by GSI and intact strength measurement. In Figure 10D, the landslide predisposed by discontinuities in the rock massif caused the retreat of the cliff (a new headscarp) and the accumulation part of the landslide increased the loading above the headscarp of the original Čertovka landslide. Loading of the disintegrated massif, 
A

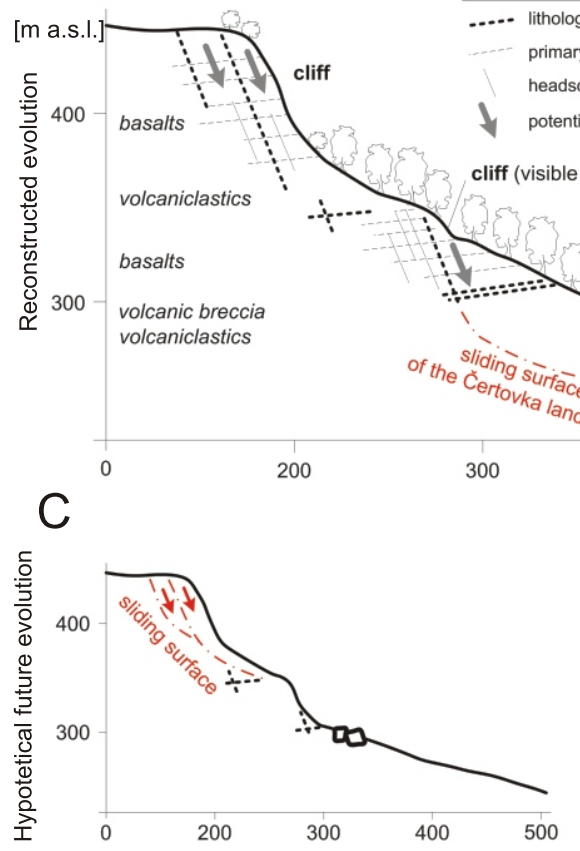

B

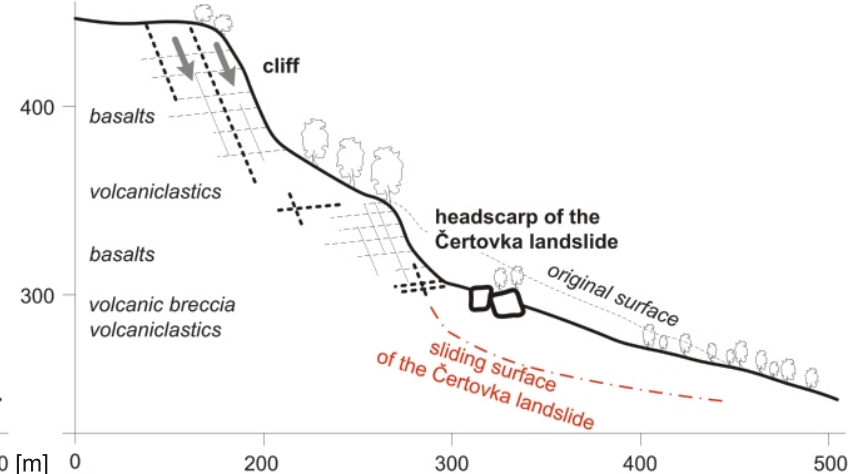

E

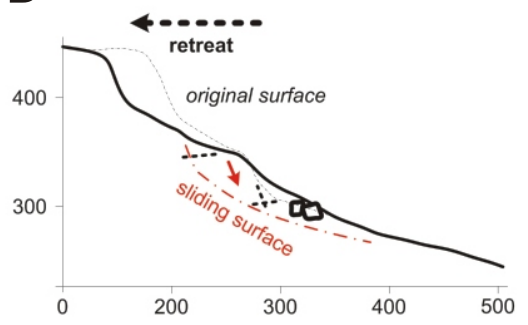

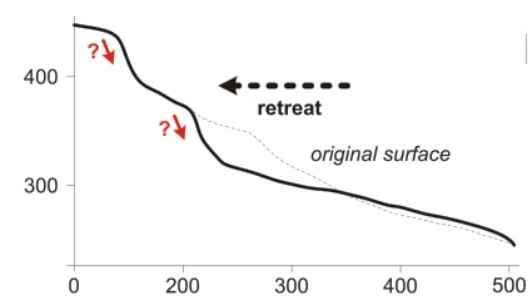

Fig. 10. Reconstructed evolution of the Čertovka landslide (A and B) and a hypothetical model of future evolution (C, D and E), indicating a slope retreat through retrogressive evolution of the headscarp

underlain by volcanic breccias and volcaniclastics, results in the reactivation of the Čertovka landslide and further retreat of its headscarp (Fig. 10E). Through this sequence of processes, the two structural levels gradually retreat in a retrogressive style also known from localities of different lithological settings (Pyszková, 2012; Travelletti et al., 2013).

\section{CONCLUSIONS}

Based on new geological, geomorphological and geophysical data, structural setting of the Čertovka landslide can be described in detail, and factors controlling the mass movement can be specified.

The Čertovka landslide should be viewed as a complex slope deformation. Its upper segment with accumulated blocks is inclined against the slope, forming a shallow trench. The middle segment is characterized by step-like morphology formed by scarps of younger landslides and flowslides, with boulder streams merged into a boulder accumulation. The sliding plane was identified at a depth of approx. $20 \mathrm{~m}$ on ERT profiles. The terminal segment of the landslide is a complex of landslide toes modified by the retaining wall.

Geological survey and borehole re-evaluation revealed that the initiation of the landslide occurred fully within the volcanic and volcaniclastic rocks of the Ústí Formation. The surface of Cretaceous sediments lies below the level of the Labe River, which excludes the involvement of these rocks in the sliding mechanism. The former diagnosis that the landslide was initiated by loading of the underlying material affected by heavy precipitation may be, however, still valid: the headscarp area and the upper tract of the landslide lie at the contact between solid basalts above and argillized volcaniclastics below. The latter lithology is also revealed by reduced bedrock resistivity values in the lower part of the longitudinal ERT profile. Low values of intact strength of the volcaniclastics were proved by Schmidt hammer readings.

A significant role in the landslide activation was undoubtedly played by subvertical discontinuities in the rock massif. Most of them can be related to the generally $\mathrm{E}-\mathrm{W}$-striking Vaňov Fault, and the headscarp of the Čertovka landslide itself probably represents the principal fault of the fault zone, as indicated by the presence of a low-resistivity zone at this point in the longitudinal ERT profile. Two generations of tectonic striae were identified at fractures dipping steeply N to NW in the headscarp area; palaeostress analysis suggests their pertinence to the Early Miocene tensional stress field (older generation) and the Late Miocene to Pliocene compressional stress field (younger generation). Other discontinuities identified in the headscarp area are NNW-SSE joints possibly pertaining to the Labe Fault, and gently south-dipping bedding planes. The complex faulting history and the presence of fractures of favourable orientation smoothed by tectonic slip are the main structural factors supporting gravitational sliding at the present relief configuration.

Along with the subvertical discontinuities in the rock massif, the fundamental precondition for landslide initiation is the step-like slope profile in the study area. The slope consists of three preserved structural levels composed of basaltic rocks in different stages of disintegration, which represent the potential source zones of landslides. While the Čertovka landslide evolved in the lower preserved structural level, future sliding activity at the landslide site will be probably connected with sliding along steep discontinuities identified by the ERT profile on the top plateau and reaching the upper structural level of the slope, up to $30 \mathrm{~m}$ from the present plateau edge. These strike parallel to the Vaňov Fault and to the present headscarp. Creation of a new headscarp upslope will increase loading of the Čertovka landslide and induce its reactivation. The subsequent sliding activity at the lower and upper structural level of the slope will thus result in a gradual slope retreat, indicating a retrogressive style.

Acknowledgements. The research was supported by the IGA UJEP project "Disturbance regimes during the Quaternary morphogenesis of the Elbe River valley in the České středohoří Mts.". The authors thank J. Blahůt, J. Melich and M. Duda for their help during the geophysical field survey, and two reviewers for their helpful comments. 


\section{REFERENCES}

Adamovič J., Coubal M. (1999) Intrusive geometries and Cenozoic stress history of the northern part of the Bohemian Massif. Geolines, 9: 5-14.

Apparao A., Roy A. (1973) Field results for direct-current resistivity profiling with two-electrode array. Geoexploration, 11: 21-44.

ASTM (1987) Standard Test Methods for the Slake Durability of Shales and Similar Weak Rocks. American Society for Testing and Materials (ASTM). Standard D4644-87. DOI: 10.1520/D4644-08

Balatka B., Kalvoda J. (1995) Vývoj údolí Labe v Děčínské vrchovině (in Czech). Sborník České geografické společnosti, 100: 173-192.

Borrelli L., Greco R., Gullí G. (2006) Weathering grade of rock masses as a predisposing factor to slope instabilities: reconnaissance and control procedures. Geomorphology, 87: $158-175$.

Burda J., Cajz V., Kadlec J., Moravcová O., Šebesta J. (1998) Nebezpečí sesuvů v údolí Labe - okres Ústí nad Labem (02-41 Ústí nad Labem) (in Czech). Zprávy o geologických výzkumech $\checkmark$ roce 1997: 130-133.

Burda J., Hartvich F., Valenta J., Smítka V., Rybář J. (2013) Climate-induced landslide reactivation at the edge of the Most Basin (Czech Republic) - progress towards better landslide prediction. Natural Hazards and Earth System Sciences, 13: 361-374.

Cajz V. (2000) Proposal of lithostratigraphy for the České středohoři Mts. volcanics. Bulletin of Czech Geological Survey, 75: 7-16.

Cajz V., Valečka J. (2010) Tectonic setting of the Ohře/Eger Graben between the central part of the České středohoři Mts. and the Most Basin, a regional study. Journal of Geosciences, 55 201-215.

Cajz V., Hroch Z., Šebesta J. (1995) Nálezová zpráva - sesuv Čertovka, katastr Vaňov 02-41-17, únor 1995 (in Czech). Czech Geological Survey, Praha.

Cajz V., Adamovič J., Rapprich V., Valigurský L. (2004) Newly identified faults inside the volcanic complex of the České středohoří Mts., Ohře/Eger Graben, North Bohemia. Acta Geodynamica et Geomaterialia, 1: 213-222.

Čech S., ed. (1991) Vysvětlivky k základní geologické mapě České republiky 1:25,000, počet listů 02-411 Ústí nad Labem (in Czech). Archive of the Czech Geological Institute, Praha.

Cílek V., Sýkorová I., Melichárková E., Melka K. (2000) Sedimentární vložky povrchového vulkanismu středohorského komplexu v okolí Čeřeniště a jejich vliv na stabilitu svahů (in Czech). Zprávy o geologických výzkumech $v$ roce 1999: 183-186.

Cruden D.M., Varnes D.J. (1996) Landslide types and processes. In: Landslides: investigation and mitigation (eds. A.R. Turner and R.L. Schuster): 36-72. Special Report 247, Transportation Research Board, National Research Council, National Academy Press, Washington D.C

Č́́ZK (2013) Shaded relief of the Basic map of the Czech Republic based on airborne laser scanning data. Český ústav zeměměřičský a katastrální, published at http://geoportal.cuzk.cz/geoprohlizec

Dužár J., Raška P., Cajz V. (2012) Geomorfologické projevy mladladě kenozoické tektoniky $v$ sz.části Milešovského středohoři (in Czech). Zprávy o geologických výzkumech v roce 2011: 75-81.

Goudie A.S. (2006) The Schmidt hammer in geomorphological research. Progress in Physical Geography, 30: 703-718.

Grelle G., Revellino P., Donnarumma A., Guadagno F.M. (2011) Bedding control on landslides: a methodological approach for computer-aided mapping analysis. Natural Hazards and Earth System Sciences, 11: 1395-1409.

Hartvich F., Mentlík P. (2010) Slope development reconstruction at two sites in the Bohemian Forest Mountains. Earth Surface Processes and Landforms, 35: 373-389.
Hartvich F., Valenta J. (2011) The identification of faults using morphostructural and geophysical methods: a case study from Strašín cave site. Acta Geodynamica et Geomaterialia, 8: 425-441.

Hartvich F., Valenta J. (2013) Tracing an intra-montane fault: an interdisciplinary approach. Surveys in Geophysics, 34: 317-347.

Hoek E., Brown E.T. (1997) Practical estimates of rock mass strength. International Journal of Rock Mechanics and Mining Sciences, 34: 1165-1186.

ISRM (1978) International Society for Rock Mechanics - suggested methods for the quantitative description of discontinuities in rock masses. International Journal of Rock Mechanics and Mining Sciences and Geomechanics Abstracts, 15: 319-368.

Klimeš J. (2002) Analysis of the causative factors of landslides triggered by the extreme rainfalls in 1997, Vsetín District, Czechia. (in Czech with English summary). Geografie - sborník ČGS, 107: $40-49$.

Klimeš J. (2009) Implications of geomorphological research for recent and prehistoric avalanches and related hazards at Huascaran, Peru. Natural Hazards, 50: 193-209.

Král V. (1966) Geomorfologie střední části Českého středohoří (in Czech). Rozpravy Československé akademie věd, řada matematických a prírodních věd, 78: 1-65.

Kurka J., Čechová E. (1997) Vaňov - zhodnocení sesuvu Čertovka (in Czech). AZ Consult. Ústí nad Labem.

Kurka J., Smolík R., Zavoral J. (1995) Vaňov - sesuv, závěrečná zpráva inženýrsko-geologického průzkumu a geotechnického kontrolního sledování (in Czech). AZ Consult, Ústí nad Labem.

Kycl P., ed. (2003) Nebezpečí svahových pohybů v jv.části Českého Středohoří na území okresu Litoměřice (in Czech). Czech Geological Survey, Praha.

Kycl P., Rapprich V., Radoň M. (2012) Geological setting of the Vaňov landslide (in Czech with English summary). Zprávy o geologických výzkumech v roce 2011: 82-86.

Loke M.H. (2012) Tutorial: 2-D and 3-D Electrical Imaging Surveys. Geotomo Software, Malaysia. www.geotomo.com

Málek J., Fischer T., Coubal M. (1991) Computation of regional stress tensor from small scale tectonic data. Publications of the Institute of Geophysics, Polish Academy of Sciences, M-15: 77-92.

Margielewski W. (2006) Structural control and types of movements of rock mass in anisotropic rocks: case studies in the Polish Flysch Carpathians. Geomorphology, 77: 47-68.

Marinos P., Hoek E. (2000) GSI: a geologically friendly tool for rock mass strength estimation. Proceedings of the GEOENG 2000 Conference, Melbourne.

Meentemeyer R., Moody A.W. (2000) Automated mapping of conformity between topographic and geological features. Computers and Geosciences, 26: 815-829.

Pánek T., Šilhán K., Tábořík P., Hradecký J., Smolková V., Lenart J., Brázdil R., Kašičková L., Pazdur A. (2011) Catastrophic slope failure and its origins: case of the May 2010 Girová Mountain long-runout rockslide (Czech Republic). Geomorphology, 130: $352-364$

Pantelidis L. (2009) Rock slope stability assessment through rock mass classification systems. International Journal of Rock Mechanics and Mining Sciences, 46: 315-325.

Pyzsková R. (2012) Elektrická odporová tomografie odlučné oblasti katastrofického sesuvu na Girové (in Czech). M.Sc. thesis. Ostrava, University in Ostrava.

Raška P. (2010) Quaternary morphogenesis of the Elbe valley in central part of the České středohoří Mts.: new data from GIS analyses and relative dating of stony accumulations and slope depressions (in Czech with English summary). Zprávy o geologických výzkumech v roce 2009: 115-119.

Raška P., Klimeš J., Dubišar J. (2013) Using local archive sources to reconstruct historical landslide occurrence in selected urban regions of the Czech Republic: examples from regions with dif- 
ferent historical development. Land Degradation and Development, DOI: 10.1002/ldr.2192

Roering J.J., Kirchner J.W., Dietrich W.E. (2005) Characterizing structural and lithologic controls on deep-seated landsliding: implications for topographic relief and landscape evolution in the Oregon Coast Range, USA. GSA Bulletin, 117: 654-668.

Rybář J., Stemberk J., Suchý J. (2000a) Aptitude of slopes stability failure in the neovolcanite region of České Středohoři Mountains (Czech Republic). In: Landslides in Research, Theory and Practice (eds. E. Bromhead, N. Dixon and M.L. Ibsen): 1285-1288. Thomas Telford Publications, London.

Rybáŕ J., Vilímek V., Cílek V. (2000b) Process analysis of deep slope failures in České středohoří neovolcanites. Acta Montana, IRSM AV CR, Ser. AB, 8: 39-46.

Scheidegger A.E. (1998) Tectonic predesign of mass movements, with examples from the Chinese Himalaya. Geomorphology, 26: $37-46$.

Schrott L., Sass O. (2008) Application of field geophysics in geomorphology: advances and limitations exemplified by case studies. Geomorphology, 93: 55-73.

Sedlák J., Glisníková V. (2008) The second phase of Čertovkalandslide (in Czech with English summary). In: Stavebni konstrukce z pohledu geotechniky: 183-187. AN CERM Brno.

Selby M.J. (1980) A rock mass strength classification for geomorphic purposes: with test from Antarctica and New Zealand. Zeitschrift für Geomorphologie, 24: 31-51.

Skácelová Z., Rapprich V., Valenta J., Hartvich F., Šrámek J., Radoň M., Gaždová R., Nováková L., Kolínský P., Pésckay Z. (2010) Geophysical research on structure of partly eroded maar volcanoes: Miocene Hnojnice and Oligocene Rychnov volca- noes (northern Czech Republic). Journal of Geosciences, 55: 299-311.

Stemberk J., Novotný J. (1996) Supplementary study of the landslide area in the Vaňov vicinity (in Czech with English summary). Studie 330/674/55. Praha, Ústav Struktury a Mechaniky Hornin AV ČR.

Suchý J. (2000) Svahové deformace labského údolí v Českém středohoři (in Czech). Ph.D. thesis, MS, Praha, PřF UK.

Synowiec G. (1999) Rock mass strength assessment for geomorphological purposes and its application to sandstone slopes in the Stołowe Mountains (in Polish with English summary). Czasopismo Geograficzne, 70: 351-361.

Šebesta J., ed. (1997) Landslide hazard in the SE part of the České středohoří Mts. in the Ústí nad Labem district area (in Czech with English summary). Czech Geological Survey, Praha.

Šebesta J., ed. (2000) Landslide hazard in the SE part of the České středohoří Mts. in the Děčín district area (in Czech with English summary). Czech Geological Survey, Praha.

Travelletti J., Malet J.-P., Samyn K., Grandjean G., Jaboyedoff M. (2013) Control of landslide retrogression by discontinuities: evidence by the integration of airborne- and ground-based geophysical information. Landslides, 10: 37-54.

Ulrych J., Dostal J., Adamovič J., Jelínek E., Špaček P., Hegner E., Balogh K. (2011) Recurrent Cenozoic volcanic activity in the Bohemian Massif (Czech Republic). Lithos, 123: 133-144.

Viles H., Vilímek V., Přikryl R., Zvelebil J. (2007) Intensity of weathering as a relative exposure age indicator of mass movements at Machu Picchu. In: Geomorphological Variations (eds. S.A. Goudie and J. Kalvoda): 127-142. P3K, Prague. 